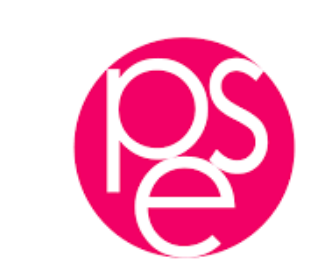

PARISSCHOOL OF ECONOMICS
ECOLE D'ECONOMIE DE PARIS

WORKING PAPER N N 2020 - 47

Conditions of Existence and Subjective Perceptions of Retirement:

Quantitative Evidence from France

\author{
Bénédicte Apouey
}

JEL Codes: J14, I14

Keywords: Retirement, Career's end, Ageing, Perceptions, Social conditions, Satisfaction, France

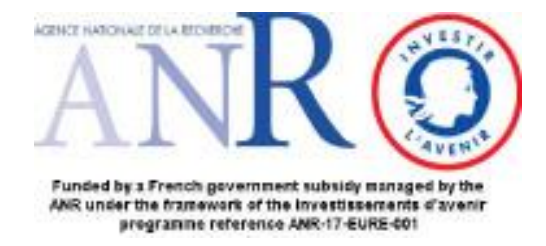




\title{
Conditions of Existence and Subjective Perceptions of Retirement: Quantitative Evidence from France
}

\author{
Bénédicte Apouey
}

July 2020

\author{
Author: Bénédicte APOUEY \\ Affiliation: Paris School of Economics - CNRS. \\ Address: 48 Boulevard Jourdan, 75014 Paris, France. \\ Phone: 33143136307. \\ Fax: 33143136355 . \\ E-mail: benedicte.apouey@psemail.eu; benedicte.apouey@gmail.com
}

Running head: Social differences in perceptions of retirement

\begin{abstract}
This article explores subjective perceptions of retirement in France, using original quantitative data on the customers of a not-for-profit insurance company. The sample contains individuals aged 4084 , who are either in the labour force $(\mathrm{N}=923)$ or retired $(\mathrm{N}=705)$. Perceptions of retirement are measured using closed questions on views of the retirement transition (these views can be positive, negative, or neutral) and definitions of retirement (retirement can be interpreted as a period of freedom, boredom, greater risk of precariousness, etc.). Using a number of different social indicators, we examine whether differences in social conditions translate into heterogeneous perceptions. We also investigate whether social differences in perceptions fade away with increasing age. Both working-age individuals and retirees generally have a positive view of the retirement transition and often define retirement as a period of freedom. Perceptions of retirement are shaped by social conditions: a higher level of education and income, greater wealth, better health, and stronger social involvement go hand in hand with rosier perceptions. Moreover, we uncover a strengthening of this social gradient with increasing age. Finally, perceptions are positively correlated with satisfaction in various domains, for retirees.
\end{abstract}

Key words: Retirement, Career's end, Ageing, Perceptions, Social conditions, Satisfaction, France.

JEL codes: J14, I14. 
Statement of ethical approval: Ethical guidelines have been met, including adherence to the legal requirement in France. The survey obtained ethics approval from the national ethics committee, i.e. "Commission Nationale de l'Informatique et des Libertés" (CNIL). The empirical work presented in the paper does not require any ethical review.

Statement of funding: The author was supported by "Chaire Transitions Démographiques, Transitions Economiques (TDTE)" hosted by "Fondation du Risque." The author prepared the questionnaire of the survey, in partnership with "Chaire TDTE," HM, and "FYM Etudes." HM funded data collection, which was implemented by "FYM Etudes." Data were provided by HM. HM, "Chaire TDTE," and "FYM Etudes" had no role in the design, execution, analysis and interpretation of data, or writing of the study.

Statement of conflict of interest: None declared.

Acknowledgements: The author thanks HM (in particular A Autret, G Bonnand, and A Chompret), Chaire TDTE (in particular F-X Albouy, M Fartaoui, M Linger, G Messanvi, A Villemeur, and H Xuan), FYM Etudes (in particular G Le Doussal), and E Macia. The views expressed in this paper are those of the author and not necessarily those of HM, "Chaire TDTE," "FYM Etudes," or the cited persons. 


\section{Introduction}

Population ageing is one of the most significant ongoing social transformations: the proportion of older persons in the population is rapidly growing in many countries. In France, while individuals aged $60+$ represented $20.4 \%$ of the population in 2000 , the share reached $23.9 \%$ in 2013 . $^{\mathrm{i}}$ Predictions show that in 2030 the proportion of people over 65 years of age will be for the first time greater than that of individuals under 20. ${ }^{\mathrm{ii}}$ In Western societies, the transition from work to retirement is experienced by most people and the retirement stage is longer than ever before.

While retirement was historically synonymous with old age, this is no longer the case. How do workers and retirees perceive retirement -- defined as the transition out of work and the life phase following this transition -- nowadays? On the one hand, the perception of retirement could be mainly negative. Indeed, in our work-oriented societies, retirement could be associated with a lack of purpose, a sense of loss, and boredom (Arbuz, 2013). ${ }^{\text {iii }}$ In addition, retirement may go hand in hand with a decrease in income and even with income precariousness. Moreover, for individuals for whom the workplace is an important context to socialize, retirement may represent a high risk of social exclusion. On the other hand, retirement may also be perceived in a more positive way, as a time of autonomy and freedom (Gestin, 2003; Repetti and Calasanti, 2018). As an example, for some people, retirement could represent an opportunity to spend time on things they never had time for before (Arbuz, 2013). According to the recent literature, respondents generally point out that retirement represents freedom (Quéniart and Charpentier, 2012; Roland-Lévy and Berjot, 2009).

In societies stratified by multiple factors, the perception of retirement is likely to be heterogeneous rather than homogeneous. Since social conditions shape individual opportunities and constraints, they are probably important structuring principles behind perceptions. According to Pierre 
Bourdieu's constructivist structuralist approach, differences in social conditions of existence (due to social positions) lead to differences in perceptions, appreciations, and practices (Bourdieu, 1987). Drawing on this theory, a qualitative study by Laberge et al. (2003) finds differences in personal notions of "ageing well" between low and high socioeconomic status (SES) women in Canada.

Gerontology researchers have argued that understanding subjective perceptions of retirement (and more generally of ageing and old age) as well as satisfaction with retirement is all the more important as they relate to future wellbeing and health. For example, poor self-perceptions of ageing $^{\text {iv }}$ (i.e. dissatisfaction with one' own ageing) at baseline increase the risk of mortality in late life (Sargent-Cox et al., 2014). Negative self-perceptions of ageing predict deterioration in general, physical, and mental health (Wurm and Benyamini, 2014). Moreover, negative attitudes to ageing as regards to "physical and psychological loss" strengthen the risk of becoming physically frail or pre-frail (Gale and Cooper, 2018).

In this article, we explore subjective perceptions of retirement in France, using recent data. Quantitative research on the relationship between social conditions and perceptions of retirement is limited for this country, as far as we know. For instance, research often collects information on these perceptions among retirees, but not younger adults. Moreover, there has been no systematic study on the link between social conditions and perceptions. Finally, whether the role of social conditions is weaker or stronger for older individuals, compared to younger ones, remains an open question. We try to fill these gaps in the literature by analysing quantitative data from an original survey, the Harmonie Mutuelle Ageing Well ("Bien Vieillir Harmonie Mutuelle" -- BVHM) survey, carried out in 2016. This survey provides information on the customers of Harmonie Mutuelle (HM) which is the largest not-for-profit insurance company in France. The sample consists of 1,628 middle-aged and older adults aged 40 to 84 . The data thus contain younger adults, "young old" 
individuals, and "old old" persons (but not "oldest old" adults). We capture subjective perceptions of retirement by asking respondents closed questions on their views of the retirement transition and on their definitions of retirement: respondents report whether they have a positive, negative, or neutral view of the retirement transition, and whether they define retirement as a time of freedom, a well-deserved rest, or a period with a greater risk of financial precariousness, among other things. Using this information, we first describe perceptions of retirement, on average, in our sample. Rather than focusing on retirees only, we explore these perceptions for economically active individuals and retirees separately and examine whether perceptions are the same or not in these two population groups. Our analysis thus complements previous work by Mutran et al. (1997) who compare attitudes toward retirement before and after retirement, using US longitudinal data. In our cross-sectional data, differences in perceptions between the two population groups could be explained by an age and/or a cohort effect. An age effect means that perceptions would change as individuals get older. Regarding the cohort effect, groups of respondents may have been exposed to different labour markets, due to the rise of employment precarity and unemployment in recent decades in France, which could translate into different perceptions. Moreover, in a context of frequent legislation changes regarding pension age and benefits in the country, active individuals may feel less secure (regarding retirement) than already retired individuals, which could lead to less positive perceptions of retirement in the active population.

We then investigate the role of the conditions of existence in the perception of retirement, by taking advantage of respondents' diverse backgrounds. We specifically focus on the influence of SES, health status, and social activities. SES is measured using information on education (which is a proxy for cultural capital) and income and wealth (which capture economic capital). Health and social activities are measured by indices of general, physical, and mental health, and involvement in community volunteering and in associations (which are related to social capital). Importantly, we 
ask whether the role of social conditions weaken or strengthen with increasing age. Exploiting original information on perceptions, as well as data on a number of social indicators, we thus try to illustrate the pervasiveness of social inequalities during the ageing process. By doing so, we supplement the qualitative study of Laberge et al. (2003) for Canada.

Finally, we check that the subjective perception of retirement correlates with mental wellbeing for retirees. We here analyse data on individual satisfaction in the finances, leisure, social life, health, and housing domains. These satisfaction domains are widely used in the literature in economics of happiness and wellbeing (Van Praag and Ferrer-i-Carbonell, 2004).

\section{Background}

To understand the ageing and retirement processes, theoretical insights from the model of the institutionalisation of the life course may be useful. In this model, the life course is structured around work and divided in three periods (which are keyed to chronological age): preparation, "activity," and retirement (Kohli, 1986). Pension systems played a major role in this institutionalisation. Some claim that a de-standardisation of life course transitions has been taking place since the 1970s: for instance, the age boundary of retirement may have become less clear. However, there is disagreement over the extent of this de-institutionalisation process: for example, while Kohli (2007) argues that de-standardisation is limited, Guillemard (2010) highlights that the process is important and goes hand in hand with insecurity and uncertainty in biographical trajectories.

In France, the retirement age has risen over the last decades. Indeed, while the country has a long tradition of social insurance, a number of pension reforms has been implemented (in 1993, 2003, 
2010, and 2014) to provide financial incentives for older workers to remain longer in the labour market. As a result of reforms, while the labour force participation of older workers was declining in the 1970s and 1980s, it has been steadily increasing since the mid-2000s, and the retirement age has risen. In 2017, people retired when they were 62.5 years old on average (including early retirement). ${ }^{\mathrm{v}}$ These recurring reforms have generated a feeling of uncertainty regarding retirement age and pension benefits, in particular among working-age individuals, which may partly lead to differences in retirement perceptions between working-age persons and retirees. Importantly, most people disagree with the increase in the retirement age in France. Indeed, the normative perception that retirement is a social right obtained by older cohorts of workers is widely shared, and many people wish this right was not progressively endangered. A survey on retirement intentions carried out in France in 2004-2005 ${ }^{\mathrm{vi}}$ shows that most respondents (aged 54-59) think that 60 is the ideal age to retire (Rapoport, 2006). Education and income level, job satisfaction, as well as health status, are positively correlated with preferred retirement age. Aouici (2016) mainly exploits qualitative data (collected in 2010) from the same survey and compares anticipated and actual retirement ages. She highlights the roles of laws, family environment, and working conditions in the gap between these ages, in particular.

Our article is closely related to the interdisciplinary literature on subjective meanings and perceptions of retirement, in France and other countries. These perceptions may have changed over the past decades, due to labour market changes, the deterioration of working conditions (Askenazy, 2004), the rise of "successful ageing" (Rowe and Kahn, 1998), retirement income growth, and life expectancy increase, among other things.

More precisely, employing survey data collected in 1955 in the Paris area, an article published in the late 1950 s showed that more than $40 \%$ of retirees reported that they were not satisfied (Treanton 
(1958) cited in Caradec (2009)). Moreover, using data from a survey carried out in 1961, a report published in the early 1960 s concluded that almost one third of individuals thought about their future retirement with apprehension (Laroque, 1962).

Caradec (2017) argues that until the 1970s, retirement was often considered as a period of rest, but that in the 1970s it started being seen as a time of leisure, and that nowadays it is often interpreted as a period of useful activities, in the omnipresent context of "active" and "successful ageing" ideals.

Accordingly, the recent literature shows that the meaning of retirement is mainly positive and that retirement is often a synonym for freedom. For instance, using data from the Survey of Health, Ageing and Retirement in Europe (SHARE), Blanchet and Debrand (2007) find that 58\% of French respondents aged 50-64 would like to transition to retirement as soon as possible. In addition, Crenner (2006) exploits quantitative data on retirees from the French "Histoire de vie" survey and highlights that transitioning to retirement is a positive experience, for most people. Two thirds of people report that they transitioned to retirement at the right time in their life. This perception depends on the type of occupation and on demographic characteristics, but not on health status, in particular. For most people, the transition to retirement takes place during a good period in their life. Moreover, in their study on 1,686 recently retired people from six European countries, Fouquereau et al. (2005) show that satisfaction with retirement is high in France. The major determinants of satisfaction with retirement are health, resources, and anticipated satisfaction. In particular, French (and British) retirees are more likely to report that regaining freedom and control, experiencing a lower level of stress and responsibilities, and engaging in social activities significantly contribute to satisfaction, compared to participants from other countries. On a related matter, Roland-Lévy and Berjot (2009) investigate social representations of retirement among 
students $(\mathrm{N}=100)$, people in the workforce $(\mathrm{N}=200)$, and recent retirees $(\mathrm{N}=50)$ in France. Social representations are assessed using a free association task (for the word "retirement") and a characterizing task. The overall representation of retirement is positive in the three population groups. However, representations are different between groups: while for students the representation is centered around "old age" (which is negatively perceived) and "time to rest" (positive in this study), working adults perceive retirement as a period of "rest," "freedom," and "free time" (positive), and the representation of retirees highlights "freedom," "less stress," "inactivity" (positive), and "end of work" (neutral). The characterizing task also shows that representations of students and adults are different. Note that positive perceptions of retirement do not imply that negative stereotypes have totally disappeared in France. Indeed, Macia et al. (2009) study stereotypes on older adults in a sample of older French $(\mathrm{N}=260)$ (and Moroccan) adults. Stereotypes are measured by asking individuals whether society perceive older adults in a positive, negative, or neutral way. Results show that age stereotypes are widespread in France: $40.4 \%$ of respondents think that they are negatively perceived, but only $20.2 \%$ think that they are positively perceived.

We take inspiration from these studies to create our measures of perceptions (see their presentation below). Consistent with these articles, our findings show that perceptions of retirement are mainly positive in our data. However, in contrast with these studies, we systematically explore heterogeneity in perceptions according to a number of social indicators and investigate whether a social convergence process takes place for older individuals.

Another strand of the literature for France provides a synthetic and general view of retirement, by presenting typologies of retirement practices (Caradec, 2015). In particular, using quantitative data, Guillemard (1972) developed a typology containing five types of practices and argued that the most 
common type is "retirement-withdrawal" ("retraite-retrait" in French), i.e. "social death," in which practices are limited to functional activities (such as bathing, sleeping, etc.). She also showed the roles of income, social relationships, health status, and education in individual practices of retirement. However, since the publication of this book, the relative importance of each type of retirement practice has changed.

Even if our paper focuses on France, it is also connected to the substantial literature on the subjective perception of retirement and ageing in other countries. For example, using quantitative longitudinal data on workers aged 58-64 from the Raleigh-Durham-Chapel Hill metropolitan area in the US in 1992 and 1994, Mutran et al. (1997) show that individuals are more positive about retirement after they become retired. Authors identify some factors influencing attitudes toward retirement, among workers and retirees. For workers in preretirement (in 1992), these factors include social background, individual identity, self-esteem, and depression. Moreover, using indepths interviews with 14 women before and after the retirement transition in the US, August (2011) highlights several meanings associated with retirement: a new period of life, a final phase, a period of losses, and a pinnacle of accomplishment or relief. Moreover, in their qualitative study of 25 interviews based on anchored theorisation, Quéniart and Charpentier (2012) explore representations of old age among women aged 65+ in Québec. Women reject the preconception on "older or elderly women" and conceptions of old age are often positive. Ageing means accepting the passage of time (i.e. physical changes) and having time for oneself and for others. For women aged 65-74, retirement offers freedom: it is a period of time when people can focus on their own interests. For women over 75, old age means the opportunity to care for loved ones. In addition, Van Dyk et al. (2013) conduct 55 qualitative interviews with retirees aged 60-72 in Germany and show that the meaning of retirement is very diverse for older people and that "late freedom" is highly valued. Repetti and Calasanti (2018) conduct a qualitative analysis with 15 Swiss retirees 
and show that both men and women describe retirement as a time of freedom. However, using a feminist gerontological approach, they find that the meaning of freedom differs between genders and reflects the gender division of labour. Finally, the study by Laberge et al. (2003) is also interesting to us because it emphasizes heterogeneity in individual notions of "ageing well" according to socioeconomic background. Building on Bourdieu's sociological theory (Bourdieu, 1979,1987 ) and using qualitative data on 36 women aged 65 to 75 in Canada, the authors show that high SES women think that ageing well means accepting declining health and maintaining a positive attitude, whereas low SES women define ageing well as having their needs met. For both low- and high-SES women, enjoying the simple pleasures of life is an important component of ageing well. ${ }^{\text {vii }}$

In a nutshell, recent studies often show that retirement is perceived in a positive way as a time of freedom. Quantitative research uncovering social differences in perceptions is limited for France. In what follows, we build on existing evidence to broaden knowledge for this country.

\section{Data and method}

Survey

Data come from the BVHM survey, which covers customers of HM and was carried out in 2016 (Apouey, 2019). First, 10,721 customers aged 40-84 were contacted by phone by a polling institute on behalf of HM and were asked whether they agreed to participate in the survey. 4,811 individuals answered in the positive and were sent a paper questionnaire. Finally, 1,769 individuals filled a questionnaire and sent it back to the polling institute. The total completion rate is rather small $(16.50 \%=100 *(1,769 / 10,721) \%)$, which is partly due to the length of the questionnaire. The sample 
was constructed using the quota method and the final sample is representative of the customers of HM along three criteria (gender, age group, and type of insurance coverage i.e. individual versus group insurance coverage). Importantly, the sample excludes the oldest old.

Data are unique in containing information on perceptions of retirement, SES, health status, social activities, and demographic characteristics. They have been used to study preparation for old age, service needs among the elderly, and perceptions of ageing well (Apouey, 2018a, 2018b, forthcoming).

In this study, we focus on individuals who are either in the economically active population or retired. We drop the small number of individuals who are not in the labour force but not retired either. The analysis sample contains 923 active individuals and 705 retirees.

\section{Subjective perceptions of retirement}

Subjective perceptions of retirement are captured by questions on the view of the retirement transition on the one hand, and on the definition of retirement on the other hand. These questions on perceptions were designed by the author, in partnership with "Chaire Transitions Démographiques Transitions Economiques" and HM.

First, the view of the retirement transition is measured using the following question: "Is your view about the transition to retirement positive or negative?" with the following possible answers: "Positive," "Negative," and "Neither positive nor negative."viii We code our variable in the following way: $1=$ Negative, $2=$ Neither positive nor negative, and $3=$ Positive. Note that this question is different from a question capturing stereotypes, which would focus on perceptions in 
society. For instance, in his study on age stereotypes, Macia et al. (2009) employ the following question: "In your opinion, how does society perceive older adults? Rather positively, rather negatively, in a neutral way."

Second, we measure definitions of retirement thanks to the following question: "In the following list of propositions, which one gives the best definition of retirement, in your opinion? (1) A welldeserved rest; (2) A period of time during which one can be bored, feel useless, or feel empty; (3) The joy of no longer hearing of work; (4) A greater risk of financial precariousness; and (5) A feeling of freedom, the feeling to start a new life." ix Respondents select one answer. The corresponding variable is thus a nominal variable with five categories. While "freedom" is clearly a positive perception whereas "boredom" and "precariousness" are negative, it is unclear to us whether "rest" is positive or negative. The importance of the response items has been highlighted in previous research on ageing. For instance, Caradec (2017) argues that the social meaning of retirement was a time of "rest" in France until the 1970s, and that this meaning is now less widespread, even if it has not completely disappeared. Moreover, in their study on social representations in France, Roland-Lévy and Berjot (2009) find that retirement means "time to rest," "rest," "freedom," "inactivity," and "end of work" for a significant share of French respondents, while Van Dyk et al. (2013) highlight the importance of "late freedom" for older individuals in Germany.

SES, health, and social activities

We measure SES using education, income, and wealth. Our SES variables thus capture both cultural capital (education) and economic capital (income and wealth). Education is coded in three categories: low education (less than "baccalauréat," which serves as the reference category), 
medium education ("baccalauréat" graduate), and high education (more than "baccalauréat"). Finally, we measure income and wealth using the logarithm of household income and wealth (plus one).

The data contain rich information on general, mental, and physical health. General health is captured by the well-known self-assessed health measure (Idler and Benyamini, 1997). Individuals indicate whether their health is very poor, poor, fair, good, or very good. Because a very small number of respondents are in very poor health, we merge the very poor and poor responses into one category. Regarding mental health, we employ the Kessler Psychological Distress Scale (K6). This self-administered scale involves six questions to estimate anxiety and mood disorders. The K6 score is an abbreviated version of the K10 scale. Higher scores indicate better mental health. Finally, for physical health, we employ a dummy for whether the individual reports that she has high blood pressure and a dummy for whether she is overweight or obese. ${ }^{\mathrm{x}}$

\section{Satisfaction in different domains}

We gather information on satisfaction in the finances, leisure, social life, health, and housing domains using the following questions: "On a scale from 0 to 10 , please indicate your level of satisfaction with the financial situation of your household / leisure / your relationship with your family, friends, and neighbours / health / housing." These satisfaction questions are widely used in the economics and psychology literature (Huppert et al., 2009; Van Praag and Ferrer-i-Carbonell, 2004). 


\section{Control variables}

We use two sets of control variables. "Controls 1" include gender, age, and marital status (i.e. a dummy capturing marital life), and "controls 2" include "controls 1" plus education, income, general health, volunteering, and involvement in an association.

When an explanatory variable (like income) has more than 75 observations with missing values, we create a dummy variable for whether information is missing and include it in our model.

\section{Method}

We estimate several regression models. First, we regress perceptions - i.e. view of the retirement transition and definition of retirement - on SES, health, and social activities, adjusting for demographic characteristics, separately for retirees and younger adults. For retirement view, which is an ordered variable, we use an ordered logit model, and for the retirement definition question, in which responses are unordered, we employ a multinomial logit model. For both explained variables, we report the average marginal effect for each category of response.

To investigate whether the effect of social conditions on perceptions changes as respondents get older, we re-estimate our model including an interaction term between social condition and age. We employ a linear model (ordinary least squares).

Last, we regress satisfaction in different domains on perceptions and control variables, for retirees, using a linear model. 
Our study is descriptive and shows correlations between our variables of interest. For instance, the association between SES, health, social activities, and retirement perceptions cannot be interpreted as the causal effect of conditions of existence on perceptions. Indeed, some reverse causality may be at work, with perceptions influencing conditions of existence. Moreover, there may be hidden factors -- such as genetic endowments, life events, and preferences -- influencing both right- and left-hand side variables. Omission of these factors may create a spurious correlation between variables.

\section{Results}

\section{Sample description}

Table A in the Supplementary Material provides summary statistics for gender, age, marital status, and conditions of existence. There are $38 \%$ of males in the economically active population, versus $47 \%$ in the retiree sample. The average age is 51 years for active individuals and 70 years for retirees. While $77 \%$ of active persons have a marital life, this is the case of $72 \%$ of retirees. There is some evidence that retirees are less educated, have a lower income, but are wealthier than active individuals. In addition, retirees are less healthy (for all health variables except mental health) and more likely to be involved in community volunteering and in associations.

Descriptive statistics for the perception variables are presented in Table 1. In the full sample, that contains both individuals in the economically active population and retirees, more than half of the respondents have a positive view of the retirement transition (52\%), and less than $10 \%$ have a negative view. Moreover, $38 \%$ of the sample has neither a positive nor a negative view. Answers to 
the question on the definition of retirement are consistent with this positive view: retirement is defined as a period of freedom by half of the sample. Moreover, 30\% of the sample report that this is a well-deserved rest. The other three possible definitions are chosen by less than $10 \%$ of the sample each.

In the descriptive statistics, perceptions seem more positive among retirees than among active individuals. Indeed, $59 \%$ of retirees have a positive view, versus $47 \%$ of active individuals. Similarly, retirement represents a period of freedom for $53 \%$ of retirees, versus $48 \%$ of active individuals; and a risk of precariousness for only $3 \%$ of retirees, but $7 \%$ of active individuals. Finally, it is defined as a well-deserved rest for $32 \%$ of retirees, versus $28 \%$ of active individuals.

However, active individuals and retirees have different socio-demographic characteristics, as shown in Table A. In a regression model that controls for gender, age, marital status, and education, we find that retirees are significantly less likely to answer "precariousness" and more likely to answer "rest" than younger adults, all other things being equal (results available upon request). There is no significant difference between the two population groups for other perception responses. Note that the model presented in Table B in Supplementary Material, which distinguishes between the employed, the unemployed, and retirees, and includes a larger number of right-hand side variables, supports these findings.

< Insert Table 1 about here >

Using descriptive statistics, we also illustrate the association between better conditions of existence and more positive perceptions. Figure 1 presents the distribution of responses to the question on retirement definitions according to income level, general health, and involvement in an association. 
Subfigures for the economically active population are presented on the left-hand side, while those for retirees are shown on the right-hand side. To generate the figure, we distinguish between individuals whose income is lower than median income and those whose income is greater than median income, individuals who report very poor or poor health and those who report fair, good, or very good health, and individuals who are involved in an association and those who are not.

In the active population, high-income individuals are more likely to define retirement as a period of freedom and less likely to define it as a period of potential precariousness. Indeed, while only $41 \%$ of low-income individuals answer "freedom," this is the case for $52 \%$ of high-income individuals. Similarly, active individuals who are in better health or who are involved in an association are more likely to mention freedom and less likely to mention the risk of precariousness.

Findings for retirees are in line with those for younger adults. However, for retirees, the gap in the definition of retirement as a period of freedom between low- and high-income individuals and between unhealthy and healthy individuals is even greater than for workers. Indeed, only $41 \%$ of low-SES individuals answer "freedom," versus 62\% of high-SES respondents. Similarly, $44 \%$ of unhealthy individuals answer "freedom," versus $63 \%$ of healthy respondents. We also find a sizeable difference in the "rest" answer between low- and high-income individuals and between unhealthy and healthy respondents. For instance, while $41 \%$ of low-income individuals answer "rest," this is the case for only $26 \%$ of high-income persons. Finally, like in the active population, being involved in an association increases the chances of defining retirement as a period of freedom. Results on social differences in views of the retirement transition are consistent with results on definitions of retirement (results available upon request).

< Insert Figure 1 about here > 
Regression results: social differences in the active population

Multivariate regression analysis indicates that higher SES, better health, and more social activities are associated with improved perceptions of retirement, all other things being equal. This result is robust to the use of different measures for SES, health, and social activities and it holds both in the economically active population and for retirees.

More precisely, in Table 2, we report marginal effects from an ordered logit (in columns (1) to (3)) and a multinomial logit (in columns (4) to (8)) model for perceptions of retirement, for the economically active population. For instance, Panel A shows the results of regressions of perceptions of retirement on education (and control variables). While there is no significant association between education and the view of the retirement transition, high education decreases the likelihood of defining retirement as a well-deserved rest and as the joy of not hearing of work, and increases the chance of defining retirement as a period of freedom. As an example, compared with a low level of education, a high level of education increases the probability of answering “freedom" by 18 percentage points.

Income and wealth also play a role: while a higher income level decreases the probability of a negative view and increases that of a positive view, greater income and wealth levels decrease the chance of defining retirement as a period or precariousness and as a well-deserved rest, and increase that of defining it as a period of freedom.

With increasingly more problematic mental health, there are more negative views of the retirement transition. Moreover, (good) mental health is positively associated with a positive view of the 
transition and is negatively associated with the probability of mentioning "precariousness." Mental and physical health is negatively associated with answering "rest." For instance, the likelihood that an individual with normal blood pressure answers "rest" is less than that of an individual with high blood pressure by 12 percentage points. Similarly, being overweight or obese increases the probability of answering "rest" by 9 percentage points. On a related matter, better general and mental health decreases the chance of defining retirement as a period of boredom. In addition, general and mental health is positively correlated with the probability of mentioning "freedom." For example, the probability that a respondent in very good health answers "freedom" is greater than that of an individual in fair health by 13 percentage points.

Finally, social activities are also associated with positive perceptions. For example, compared with individuals who do not volunteer, individuals who volunteer are more likely (by 10 percentage points) to have a positive view of the retirement transition; and respondents who are involved in an association are more likely (by 14 percentage points) to define retirement as a time of freedom.

$<$ Insert Table 2 about here >

Regression results: social differences for retirees

Like in the economically active population, SES, health, and social activities are positively correlated with positive perceptions, for retirees.

In this population group, none of the SES variables is significantly associated with views of retirement (Table 3). However, all three SES measures are negatively correlated with the definitions emphasizing "rest" and "precariousness" and positively correlated with the definition highlighting 
"freedom." Compared with a low level of education, a high level of education increases the probability of answering "freedom" by 28 percentage points, and decreases the likelihood of answering "rest" and "precariousness" by 25 and 4 percentage points.

General, mental, and physical health is negatively correlated with a negative view of retirement (and positively associated with a positive view). Moreover, better health decreases the likelihood of defining retirement as a well-deserved rest, a period of boredom, the joy of not hearing of work, and a risk of precariousness, and increases the chance of defining retirement as a time of freedom. Very good health decreases the probability of answering "rest" and "the joy of not hearing of work" by 17 and 6 percentage points, while increasing the probability of mentioning "freedom" by 26 percentage points (compared to fair health).

Social activities also go hand in hand with more positive views and definitions. For example, volunteering increases the probability of answering "freedom" by 13 percentage points.

< Insert Table 3 about here >

Regression results: full models

In Tables 2 and 3, we explored the roles of SES, health, and social activities separately. We now estimate a full model that includes several indicators of social conditions at the same time (education, income, general health, volunteering, and association). Results (presented in Table B in Supplementary Material) indicate that each family of social condition variables has an independent effect on perceptions. More precisely, even when we control for health and social activities, a higher income goes hand in hand with rosier definitions. Similarly, in this full model, better health 
still decreases the likelihood of negative perceptions while strengthening that of positive ones. Social activities also play an independent beneficial role.

In this full model, the role of education is complex: on the one hand, high education is positively correlated with a negative view of the retirement transition (and negatively correlated with a positive view), but it also increases the likelihood of defining retirement as a time of freedom.

Although this is not our prime concern, the analysis enables us to know whether gender, age, and marital status are important structuring principles behind perceptions or not. First, we generally do not find any significant difference between females and males. However, this probably does not imply that there is no gender discrepancy in perceptions. Indeed, previous research shows that ageing is a gendered process (Bozon et al., 2018; Foster and Walker, 2013), due to differences in work trajectory (Bué, 2002), domestic and caring activities (Craig et al., 2010; Haberken et al., 2015), and health status and life expectancy (Cambois et al., 2017; Van Oyen et al., 2013) between females and males, in particular. Moreover, the literature also finds that men and women have different retirement expectations and describe retirement in different ways (Onyx and Baker, 2006; Repetti and Calasanti, 2018). In our study, it may simply be the case that our variables are not precise enough to capture gender differences. Using an in-depth qualitative method may thus be useful to better assess the influence of gender on perceptions.

Second, age is positively associated with positive views of the retirement transition (and negatively correlated with negative views). Moreover, the answer "freedom" becomes more common with increasing age. These changes with age could mean that individuals embrace new social norms as they get older, although our data do not enable to test this hypothesis. 
Finally, not having a partner has a detrimental impact on perceptions, since it decreases (resp. increases) the likelihood of positive (resp. negative) views and increases the likelihood of defining retirement as a period of potential precariousness. This results is unsurprising, given the positive influence of having a spouse/partner while adjusting to retirement and re-organizing weekly activities (Caradec, 2015).

Does the effect of social conditions on perceptions weaken with age? To investigate this point, we re-estimate our full model including interaction terms between social condition and age (Table $\mathrm{C}$ in Supplementary Material). There is some evidence that a divergence process is taking place, meaning that the relationship between social conditions and perceptions strengthens with age. For instance, the correlation between education or income and the likelihood of responding "rest" (is negative starting age 41 for education and 54 for income and) decreases with age, while the association between income and the likelihood of responding "freedom" (is positive starting age 42 and) increases with age. ${ }^{x i}$ In other words, a higher income level is associated with a smaller probability of responding "rest" and this negative income impact is even more negative for older individuals. Symmetrically, a higher income level increases the probability of mentioning "freedom" and this effect is greater for older individuals. In contrast, the association between social activities (i.e. volunteering and association) and perceptions remains stable with age.

\section{Rosier perceptions of retirement correlate with higher satisfaction for retirees}

Finally, we check that rosier retirement perceptions are associated with higher levels of wellbeing for retirees. Specifically, we regress the satisfaction variables on the view of the retirement transition and on the definition of retirement (see Table D in Supplementary Material). We alternatively include "controls 1 " and "controls 2 " to check the robustness of findings. Compared 
with a view of retirement transition that is neither negative nor positive, a positive view is correlated with greater satisfaction in all domains, for the two sets of control variables. Findings on the definition of retirement support these results. People who define retirement as a period of precariousness report lower satisfaction in the finances, leisure, and health domains (when either "controls 1" or "2" are included) and in the housing domain (when "controls 1" are accounted for). In contrast, individuals who define retirement as a period of freedom report higher levels of wellbeing in all domains, when "controls 1" are included, and in the social life and housing domains, when "controls 2" are included. Surprisingly, we also find that a negative view of retirement, as well as a definition of retirement as a period of boredom, is positively associated with satisfaction with financial situation. However, our results generally show that perceptions are closely related to individual wellbeing, with the expected signs.

\section{Discussion}

Employing quantitative data on a diverse sample of French respondents, we show that perceptions are undoubtedly positive: $52 \%$ of respondents have a positive view of the retirement transition (while only $10 \%$ have a negative view), and the most common definition of retirement is a period of freedom, both among younger adults and retirees. Our finding is thus in stark contrast with the negative stereotype associated with age: for our respondents, retirement does not mean social exclusion or "social death" (Guillemard, 2002). Our result is consistent with recent qualitative findings for Switzerland, that show that retirees describe retirement as a time of freedom (Repetti and Calasanti, 2018). It also corroborates earlier results on the positive social representations of retirement in France (Roland-Lévy and Berjot, 2009) and old age in Canada (Quéniart and Charpentier, 2012). These findings on the positive image of retirement are not surprising given the 
power of our society's norm of "successful ageing" and the growing culture of personal selffulfilment (retirement is then perceived as a period during which one may realise her potential).

In the context of longer working lives in France (related to public policies, including pension reforms), these positive views of retirement may also mean that retirement is more rewarding than working life for some respondents. Previous research for France has highlighted that some older people are exposed to poor working conditions during the last years of their working lives, due to the general deterioration of working conditions since the 1980s (Khireddine-Medouni et al., 2016; Pailhé, 2005) and to the negative perception of older workers in the workplace. For instance, some older workers are affected by negative relationships with colleagues and get boring tasks (Aouici, 2016). In addition, some older workers are excluded from the labour market because of forced (early) retirement or unemployment (Salembier, 2015). These conditions and constraints generate stress, job dissatisfaction, and a feeling of being a burden in the workplace. This may partly explain the positive perception of retirement, by contrast with work (or unemployment).

Perceptions of retirement are different between retirees and younger adults in France: retirees are less likely to define retirement as a risk of financial precariousness, but more likely to define it as a period of rest (all other things being equal). Note that Mutran et al. (1997) also find differences in attitudes toward retirement, using US longitudinal data: in their study, attitudes are more positive among respondents who retire than among those who continue to work. In our cross-sectional data, the difference between retirees and younger adults may be interpreted as an age and/or a cohort effect. First, it could be due to a life stage effect: people would have different views about retirement after experiencing this new stage of life. Second, the difference between workers and retirees may also reflect differences in life trajectories, anticipations, or socializations between cohorts. In the context of recurring pension reforms (to improve sustainability) in France, younger 
cohorts may anticipate that their retirement income will decrease (Caradec, 2017), which may explain why they put more emphasis on the risk of precariousness than retirees (cohort effect). Younger cohorts may also anticipate higher risks of financial precariousness during retirement because they experience higher degrees of employment insecurity during their working life, which goes hand in hand with lower pension payments (cohort effect). Understanding the gap in perceptions between the two population groups is an important avenue for future research.

Do subjective perceptions of retirement depend on social and material circumstances? We quantitatively examine this point using a large number of social condition indicators. Indeed, social conditions (high SES, good health, and social involvement) may provide resources that help individuals cope with retirement and ageing. These resources may enable individuals to prepare (financially) for retirement (Apouey, 2018b), to reorganize their life after retirement, and to develop some (non-work) aspects of their identity. Our analysis confirms that perceptions markedly vary according to social position. Importantly, these social differences are found for both active individuals and retirees. Our result seems robust, since social heterogeneity emerges in descriptive statistics, but remains statistically significant in regression models, all other things being equal. For instance, household income, which is a proxy for economic hardship, is negatively associated with defining retirement as a period of potential precariousness. Similarly, superior economic and cultural capital allows respondents more often to perceive retirement as a period of freedom. Moreover, while these social differences are observed for a variety of social condition indicators (SES, health, and social capital measures), each social condition variable plays an independent role, which points to the cumulative effects of the different forms of capitals (see the full model). The effects we uncover are large: for instance, in our full model, high education increases the probability of perceiving retirement as a period of freedom by 12 percentage points (compared to low education). 
While "rest" was the main social meaning of retirement until the 1970s (Caradec, 2017), retirement still means "rest" for a high share of respondents (approximately 30\%) in our very recent data. Among retirees and individually active individuals, the probability of answering "rest" is significantly correlated with low SES and poor health. We hypothesize that this response is linked to poor working conditions or precarity on the labour market.

More generally, our results on the role of social conditions are consistent with previous evidence on differences in personal definitions of "ageing well" in France (Apouey, forthcoming) and Canada (Laberge et al., 2003). It is entirely possible that social differences in perceptions of retirement and ageing echo social differences in perceptions of working life. However, longitudinal data that would follow individuals before and after the retirement transition would be necessary to test this hypothesis. In any case, using original data on perceptions, our work emphasizes the persistence of social inequalities during the retirement period. We also provide evidence of divergence in perceptions of retirement between individuals from different social backgrounds with increasing age. Again, this result could be due to an age or a cohort effect. In the case of an age effect, our result may mean that the adverse effect of poor social conditions on perceptions accumulate as individuals get older.

While our analysis emphasizes social differences, some common features also emerge between social classes. In particular, in both low- and high-income groups, the most common definition of the retirement is a period of freedom (see the descriptive statistics).

Finally, we check that positive perceptions of retirement are associated with greater wellbeing (i.e. satisfaction in several life domains) for retirees. These associations remain significant (but are 
attenuated) when we adjust for covariates. This result speaks to previous findings on the link between age stereotypes and satisfaction in Germany (Kornadt and Rothermund, 2011), for instance.

One important limitation of our study is that our sample is not representative of the entire French population, but of the customers of a large insurance company. In particular, compared with the French population of the same age group, the average individual in our sample is more likely to be married and to be a home-owner. For this reason, our results should be interpreted with some caution and further research based on a nationally representative is needed. Another limitation is that respondents may not understand questions on retirement perception and response categories in the exact same way. For example, in the response category "a feeling of freedom," the meaning of the word "freedom" could be different for low- and high-income individuals. In addition, our questionnaire lists a relatively small number of definitions of retirement, and it is thus possible that some important definitions are omitted: for instance, retirement may represent an opportunity to care for loved ones. To address this point, future quantitative research should include a broader set of definitions. Moreover, while we focus on a number of SES, health, and social activities measures, other variables, such as former occupation (for retirees) and the spouse's occupation, may also shape perceptions. Finally, our results cannot be interpreted as causal relationships, as discussed above.

In closing, the strengths of our study include the description of perceptions of retirement in France, the study of heterogeneity, and the use of a relatively large sample of respondents. Our findings point to the importance of social conditions in shaping perceptions of retirement. We also find that perceptions are associated with satisfaction in different domains. Future research should try to uncover the mechanisms behind these associations, in the context of successful ageing ideals. 


\section{References}

Aouici, S (2016) Le Passage à la Retraite en Période de Réformes: Vécu et Expériences. Retraite et Société 74: 117-144.

Apouey, B (Forthcoming) Inégalités Socioéconomiques et Définitions Subjectives du Bien Vieillir : Résultats d'une Enquête Quantitative. Retraite et Société.

Apouey, B H (2019) Présentation de l'Enquête Bien vieillir Harmonie Mutuelle. Working Paper, Paris School of Economics.

Apouey, B H (2018a) Les Attentes en Termes de Services pour les Seniors: Le Rôle de l'Altruisme et de l'Anticipation de la Dépendance. Revue Française d'Economie 33: 15-74.

Apouey, B H. (2018b) Preparation for Old Age in France: The Roles of Preferences and Expectations. The Journal of the Economics of Ageing 12: 15-23.

Apouey, B H, Guven, C and Senik, C (2019) Retirement and Unexpected Health Shocks. Economics \& Human Biology 33: 116-123.

Arbuz, G (2013) Le Départ à la Retraite : Perceptions et Accompagnement. Retraite et Société 65: $168-178$.

Askenazy, P (2004) Les Désordres du Travail : Enquête sur le Nouveau Productivisme. Paris: Seuil.

August, R A (2011) Women's Retirement Meanings: Context, Changes, and Organizational Lessons. Gender in Management: An International Journal 26: 351-366.

Blanchet, D and Debrand, T (2007) Aspiration à la Retraite, Santé et Satisfaction au Travail : Une Comparaison Européenne. Irdes Working Paper Series.

Bourdieu, P (1979) La Distinction. Critique Sociale Du Jugement. Paris: Editions de Minuit.

Bourdieu, P (1987). Choses Dites. Paris: Editions de Minuit.

Bozon, M, Gaymu, J and Lelièvre, E (2018) L'Expérience du Vieillissement Autour de la Soixantaine en France. Age Subjectif et Genre. Ethnologie Française 171: 401-412.

Bué, J (2002) Temps Partiel des Femmes : Entre Choix et Contraintes. Premières Synthèses, DARES. Number 08.2.

Cambois, E, Garrouste, C and Pailhé, A (2017) Gender Career Divide and Women's Disavantage in Depressive Symptoms and Physical Limitations in France. SSM - Population Health 3: 81-88.

Caradec, V (2009) Retraite 'à la Carte' et 'Libre Choix' Individuel. Réflexion sur les Transformations Contemporaines de la Retraite. Gérontologie et Société 32: 25-43.

Caradec, V (2015) Sociologie de La Vieillesse et Du Vieillissement. Paris: Armand Colin.

Caradec, V (2017) L'épreuve de la Retraite. Transformations Sociétales, Expériences Individuelles. Nouvelle Revue de Psychosociologie 1: 17-29.

Craig, L and Mullan, K (2010) Parenthood, Gender and Work-Family Time in the United States, Australia, Italy, France, and Denmark. Journal of Marriage and Family 72: 1344-1361.

Crenner, E (2006) Etre Retraité : Quelle Identité Après le Travail ? Economie et Statistique 393394: 41-60.

Dave, D, Rashad, I and Spasojevic, J (2008) The Effects of Retirement on Physical and Mental Health Outcomes. Southern Economic Journal 75: 497-523.

Foster, L and Walker, A (2013) Gender and Active Ageing in Europe. European Journal of Ageing 10: $3-10$.

Fouquereau, E, Fernandez, A, Fonseca, A M, Paul, M C and Uotinen, V (2005) Perceptions of and Satisfaction with Retirement: A Comparison of Six European Union Countries. Psychology and Aging 20: 524-528.

Gale, C R and Cooper, C (2018) Attitudes to Ageing and Change in Frailty Status: The English Longitudinal Study of Ageing. Gerontology 64: 58-66.

Gestin, A (2003) Temps, Espaces et Corps à la Retraite : Des Paradoxes à Penser. L'Homme \& La Société 1: 169-190. 
Guillemard, A-M (1972) La Retraite, Une Mort Sociale. Paris: Mouton.

Guillemard, A-M (2010) Les Défis du Vieillissement. Age, Emploi, Retraite, Perspectives Internationales. Armand Colin.

Guillemard, A-M (2002) De la Retraite Mort Sociale à la Retraite Solidaire. Gérontologie et Sociétés 3: 53-66.

Haberkern, K, Schmid, T and Szydlik, M (2015) Gender Differences in Intergeneraional Care in European Welfare States. Ageing and Society 35: 298-320.

Huppert, F A, Marks, N, Clark, A, Siegrist, J, Stutzer, A, Vitters $\varnothing$, J and Wahrendorf, M (2009) Measuring Well-Being across Europe: Description of the ESS Well-Being Module and Preliminary Findings. Social Indicators Research 91: 301-315.

Idler, E L and Benyamini, Y (1997) Self-Rated Health and Mortality: A Review of Twenty-Seven Community Studies. Journal of Health and Social Behavior 38: 21-37.

Khireddine-Medouni, I, Lemaître, A, Homère, J, Plaine, J, Garras, L, Riol, M-C and Valenty, M (2016) Augmentation des Taux de Prévalence de la Souffrance Psychique en Lien avec le Travail chez les Salariés Actifs en France entre 2007 et 2012, à Partir du Programme MCP. Archives des Maladies Profesionnelles et de l'Environnement 77: 438.

Kohli, M (1986) The World We Forgot: A Historical Review of the Life Course. In Later Life: The Social Psychology of Ageing, edited by V. W. Marshall, 271-303. Beverly Hills, CA: Sage.

Kohli, M (2007) The Institutionalization of the Life Course: Looking Back to Look Ahead. Research in Human Development 4: 253-271.

Kornadt, A E and Rothermund, K (2011) Contexts of Aging: Assessing Evaluative Age Stereotypes in Different Life Domains. The Journals of Gerontology: Series B 66B: 547-556.

Laberge, S, Dumas, A, Rail, G, Dallaire, H and Voyer, P (2003) Les Conceptions Du «BienVieillir » d'aînées de Milieux Favorisés et Défavorisés. Revue Québécoise de Psychologie 24: 71-93.

Laroque, P (1962) Politique de La Vieillesse. Paris: La Documentation Française.

Macia, E, Lahmam, A, Baali, A, Boetsch, G and Chapuis-Lucciani, N (2009) Perception of Age Stereotypes and Self-Perception of Aging: A Comparison of French and Moroccan Populations. Journal of Cross-Cultural Gerontology 24: 391-410.

Mutran, E J, Reitzes, D C and Fernandez, M E (1997) Factors That Influence Attitudes toward Retirement. Research on Aging 19: 251-273.

Onyx J, Baker E (2006) Retirement expectations: gender differences and partner effects in an Australian employer-funded sample. Australasian Journal on Ageing 25: 80-83.

Pailhé, A (2005) Working Conditions: How are Older Workers Protected in France? Population 60: 93-118.

Quéniart, A and Charpentier, M (2012) Older Women and Their Representations of Old Age: A Qualitative Analysis. Ageing and Society 32: 983-1007.

Rapoport, B (2006) Les Intentions de Départ à la Retraite des Salariés du Privé Agés de 54 à 59 Ans. DREES. Etudes et Résultats.

Repetti, M and Calasanti, T (2018) 'Since I Retired I Can Take Things as They Come. For Example, the Laundry': Gender, Class and Freedom in Retirement in Switzerland. Ageing \& Society 38: 1556-1580.

Roland-Lévy, C and Berjot, S (2009) Social Representations of Retirement in France: A Descriptive Study. Applied Psychology 58: 418-434.

Rowe, J W and Kahn, R L (1998) Successful Aging: The MacArthur Foundation Study. Pantheon. New York.

Salembier, L (2015) Fins de Carrière Autour des Années 2000 : Une Hausse des Situations de Chômage à l'Approche des 60 ans. Etudes et Résultats, Drees, number 0917.

Sargent-Cox, K A, Anstey, K J and Luszcz, M A (2014) Longitudinal Change of Self-Perceptions of Aging and Mortality. The Journals of Gerontology: Series B 69: 168-173. 
Treanton, J-R (1958) Les Réactions à la Retraite. Une Étude Psycho-Sociologique. Revue Française Du Travail 12: 149-165.

Van Dyk, S, Lessenich, S, Denninger, T and Richter, A (2013) The Many Meanings of 'Active Ageing'. Confronting Public Discourse with Older People's Stories. Recherches Sociologiques et Anthropologiques 44: 97-115.

Van Oyen, H, Nusselder, W, Jagger, C, Kolip, P, Cambois, E and Robine, J-M (2013) Gender Difference in Healthy Life Years Within the EU: An Exploration of the "Health-Survival" Paradox. International Journal of Public Health 58: 143-155.

Van Praag, B M S and Ferrer-i-Carbonell, A (2004) Happiness Quantified: A Satisfaction Calculus Approach. New York: Oxford University Press.

Wurm, S and Benyamini, Y (2014) Optimism Buffers the Detrimental Effect of Negative SelfPerceptions of Ageing on Physical and Mental Health. Psychology \& Health 29: 832-848.

Zhu, R (2016) Retirement and Its Consequences for Women's Health in Australia. Social Science \& Medicine 163: 117-125. 


\section{Tables and figures}

Table 1: Descriptive statistics

\begin{tabular}{lccc}
\hline & \multicolumn{3}{c}{ Proportions (\%) } \\
\cline { 2 - 4 } & $\begin{array}{c}\text { Full } \\
\text { sample }\end{array}$ & $\begin{array}{c}\text { Economically } \\
\text { active } \\
\text { population }\end{array}$ & Retirees \\
\hline View of the retirement transition & 9.6 & 12.7 & 5.5 \\
Negative & 38.3 & 40.8 & 35.2 \\
Neither negative nor positive & 52.1 & 46.5 & 59.3 \\
Positive & 100 & 100 & 100 \\
Total & & & \\
& & & \\
Definition of retirement & 29.9 & 28.1 & 32.2 \\
A well-deserved rest & 6.6 & 7.2 & 5.9 \\
A period of time during which one can be bored, & & & \\
feel useless, or feel empty & 8.3 & 10.0 & 6.2 \\
The joy of no longer hearing of work & 5.0 & 6.5 & 3.0 \\
A higher risk of financial precariousness & 50.2 & 48.2 & 52.7 \\
A feeling of freedom, the feeling to start a new life & 500 & 100 & 100 \\
Total & 100 & \\
\hline Diffencs in pections betwen the econgis
\end{tabular}

Notes: Differences in perceptions between the economically active population and retirees are statistically significant at conventional levels (except for "A period of time during which one can be bored, feel useless, or feel empty" for which the difference is not significant). 
Table 2: Correlates of perception of retirement, in the economically active population

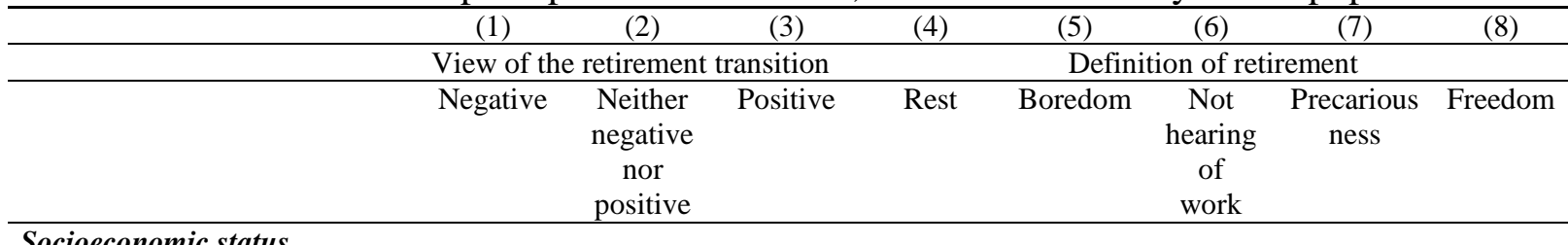

Panel A. Education

Low edu

Medium edu

High edu

Panel B. Income

$\operatorname{Ln}($ income +1$)$

Panel C. Wealth

$\operatorname{Ln}($ wealth+1)
$-0.004$

(0.005)

$\begin{array}{cc}\text { Ref } & \text { Ref } \\ -0.021 & -0.027 \\ (0.018) & (0.025) \\ -0.008 & -0.010 \\ (0.016) & (0.019)\end{array}$

\section{Ref}

0.049

$(0.043)$

0.018

(0.036)

(0.019)

$-0.019 * * \quad-0.022 * *$

(0.009)

(0.010)

$0.041 *$

(0.019)

$-0.005$

(0.005)
0.009

(0.010)
Ref

$-0.057$

(0.042)

$-0.139 * * *$

(0.033)

Ref

0.012

(0.024)

0.014

$(0.020)$

Ref

$-0.054 * *$

$(0.026)$

$-0.047 * *$

(0.023)

Ref

0.012

$(0.023)$

$-0.008$

0.087 *

$(0.045)$

$0.181 * * *$

$(0.037)$

$063 * * *$

$(0.020)$

$-0.007$

$-0.019$

$0.028 * * *$

(0.012)

(0.013)

(0.007)

$0.118 * * *$

$0.026)$

Health

Panel D. General health

Very poor or poor

Fair

Good

Very good

0.002

(0.031)

0.002

(0.030)

Ref

Ref

$-0.028$

$-0.024$

$(0.017)$

(0.019)

$-0.029$

$-0.035$

(0.026)

$-0.004$

(0.062)

Ref

0.052

(0.035)

$-0.020 * *$

0.002

$-0.010 *$

(0.009)

(0.006)

(0.006)

$-0.014 * * * \quad 0.043 * * *$

(0.005) (0.010)

0.065

(0.047)

$-0.031$

(0.060)

$-0.022$

(0.034)

$-0.000$

(0.042)

$0.077 *$

$-0.024$

Ref

Ref

Ref

0.041

(0.065)

$-0.058 * \quad-0.021$

$-0.025$

(0.035)

$(0.021)$

(0.024)

Ref

Ref

$-0.062$

$-0.043 *$

$-0.011$

$(0.018)$

$0.114 * * *$

(0.045)

(0.024)

$(0.031)$

$-0.012 \quad 0.129 * *$

(0.038)

$(0.024) \quad(0.050)$

Panel E. Mental health

Good mental health (K6 scale)

$-0.005^{* * *}$

$(0.002)$

$-0.006^{* * *}$

Panel F. High blood pressure

High blood pressure

$\begin{array}{lccccccc}-0.021 & -0.029 & 0.050 & 0.118^{*} & -0.043 * & -0.008 & -0.045^{* *} & -0.023 \\ (0.025) & (0.039) & (0.065) & (0.067) & (0.024) & (0.040) & (0.020) & (0.068) \\ & & & & & & & \\ -0.003 & -0.004 & 0.007 & 0.091 * * * & -0.004 & -0.018 & -0.026 & -0.042 \\ (0.014) & (0.018) & (0.031) & (0.030) & (0.017) & (0.020) & (0.016) & (0.034)\end{array}$

Panel G. Overweight or obese

Overweight or obese

(0.014)

(0.018)

(0.031)

(0.030)

(0.017)

(0.020)

$(0.034)$

\section{Social activities}

Panel H. Social activities

Volunteering

$-0.046 * *-0.056 * *$

$(0.020) \quad(0.024)$

$0.102 * *$

$0.090 * *$

$-0.014$

0.004

$-0.086^{* *} \quad 0.006$

$(0.020)$
-0.012

$-0.015$

(0.043)

(0.040)

(0.025)

(0.028)

(0.043)

(0.049)

(0.016)

(0.036)

(0.036)

(0.019)

(0.023)

$(0.032)$

(0.039)

Controls 1

Yes Yes

Yes Yes

Yes Yes

Yes

Yes

$923 \quad 923$

919

919

$919 \quad 919$

919

Notes: Each column and panel corresponds to a specific regression. Columns (1) to (3) contain marginal effect from a ordered logit model. Columns (4) to (8) report marginal effects from a multinomial logit model. "Controls 1" are included, i.e. gender, age, and marital status. Standard errors in parentheses.

$* * * \mathrm{p}<0.01, * * \mathrm{p}<0.05, * \mathrm{p}<0.1$. 
Table 3: Correlates of perception of retirement, for retirees

\begin{tabular}{lccccccc}
\hline & $(1)$ & $(2)$ & $(3)$ & $(4)$ & $(5)$ & $(6)$ & $(7)$ \\
\hline \\
\hline
\end{tabular}

Panel A. Education

Low edu

Medium edu

High edu

Panel B. Income

$\operatorname{Ln}($ income +1$)$

Panel C. Wealth

$\operatorname{Ln}($ wealth+1)
$(0.003)$

\section{Ref}

$-0.006$

$(0.010)$

0.004

$(0.011)$

$-0.002$

$(0.007)$

$-0.008$

(0.027)

$-0.003$

$(0.011)$

$(0.040)$

$(0.039)$

Ref
0.032
$(0.050)$
-0.016
$(0.050)$

Ref

$(0.043) \quad(0.026)$

(0.050)

$(0.040)$

0.042

(0.028)

\section{Ref}

0.002

$(0.027)$

$-0.030$

$(0.020)$

Ref

$-0.009$

(0.018)

$-0.037 * * *$

(0.009)

Ref

$0.184 * * *$

(0.050)

$0.278 * * *$

(0.047)

\section{$0.011-0.203 * * *$}

0.017

$-0.044 * * *$

$\begin{array}{lll}(0.034) & (0.030) \quad(0.020)\end{array}$

(0.014)

$-0.024 * * *$

$0.255^{* * *}$

$0.035)$

0.003

(0.014)

$-0.055^{* * *}$

0.000

$-0.008$

(0.035)

$.072 * * *$

$(0.013)$

$-0.010 * *$

(0.006)

(0.004)

Health

Panel D. General health

Very poor or poor

Fair

Good

Very good

$\begin{array}{cc}0.016 & 0.051 \\ (0.015) & (0.046) \\ \text { Ref } & \text { Ref } \\ -0.007 & -0.029 \\ (0.008) & (0.033) \\ -0.024 * * & -0.112 * * \\ (0.010) & (0.052)\end{array}$

-0.067
$(0.061)$

$-0.029$

(0.059)

$-0.001$

0.015

Ref

Ref

(0.033)

(0.036)

0.044
$(0.027)$

$-0.030$

0.036

$-0.119 * * * \quad-0.026$

Ref

Ref

$(0.062)$

(0.041)

(0.040)

$-0.026$

$-0.003$

0.006

Ref

$0.136 * *$

$-0.165 * * *$

$-0.033$

(0.021)

(0.013)

$0.142 * * *$

$(0.061)$

(0.058)

(0.028)

$-0.056 * * *$

$-0.006$

(0.042)

(0.020)

$(0.017)$

$0.260 * * *$

(0.062)

Panel E. Mental health

Good mental health (K6 scale)

$-0.003 * * \quad-0.011 * * * \quad 0.014 * * *$

(0.001)

(0.004)

(0.005)

$-0.008$

$-0.007 * * *$

$-0.005 * *$

$-0.005 * * *$

$0.024 * * *$

(0.005)

(0.002)

(0.002)

(0.002)

(0.005)

Panel F. High blood pressure

High blood pressure

$-0.00$

(0.011)

$-0.016$

0.020

$0.121 * *$

$-0.015$

(0.052)

(0.023)

$0.066^{*}$

(0.034)

0.001

(0.017)

$-0.172 * * *$

Panel G. Overweight or obese

Overweight or obese

$0.019 * * \quad 0.075 * * \quad-0.094 * * \quad 0.07$

(0.008) (0.030)

(0.037)

$0.075^{* *}$

0.007

$0.034 *$

0.003

(0.013)

$-0.118^{* *}$

(0.018) (0.018)

(0.039)

\section{Social activities}

Panel H. Social activities

Volunteering

$\begin{array}{ccc}-0.020 * * & -0.072 * * & 0.092 * * \\ (0.010) & (0.034) & (0.044) \\ -0.018 * * & -0.065 * * & 0.083 * * \\ (0.009) & (0.030) & (0.038)\end{array}$

$0.005-0.075^{* * *}$

$-0.027$

$0.127 * * *$

(0.042)

$(0.021)$

$(0.032)$

$(0.022)$

(0.045)

Association

(0.037)

(0.021)

(0.020)

Controls 1

Yes Yes Yes

Yes Yes Yes

Yes

Yes

Observations

$705 \quad 705$

705

704

$704 \quad 704$

704

704

Notes: Each column and panel corresponds to a specific regression. Columns (1) to (3) contain marginal effect from an ordered logit model. Columns (4) to (8) report marginal effects from a multinomial logit model. "Controls 1" are included, i.e. gender, age, and marital status. Standard errors in parentheses.

$* * * \mathrm{p}<0.01, * * \mathrm{p}<0.05, * \mathrm{p}<0.1$. 
Figure 1: Retirement definitions by income level, health status, and association involvement

Economically active population
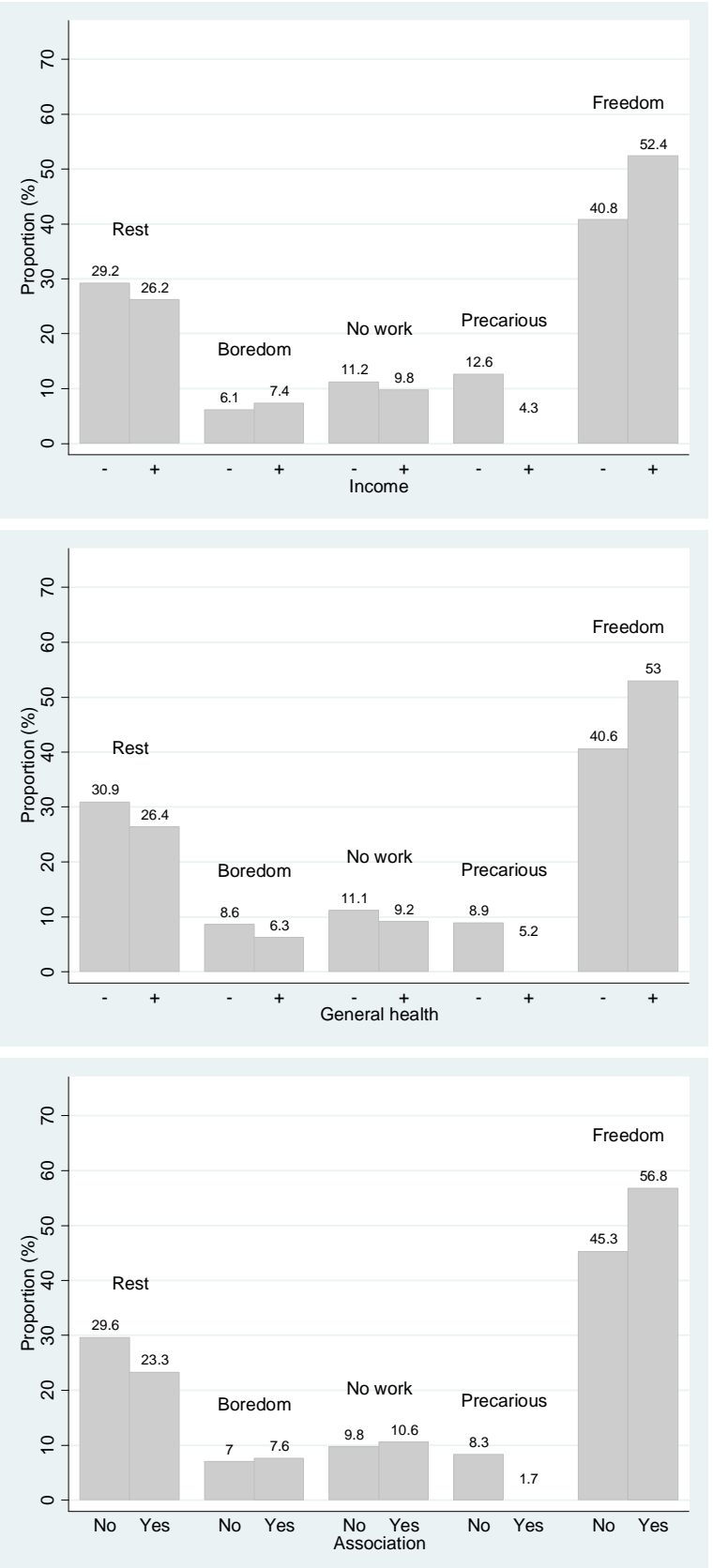

Retirees
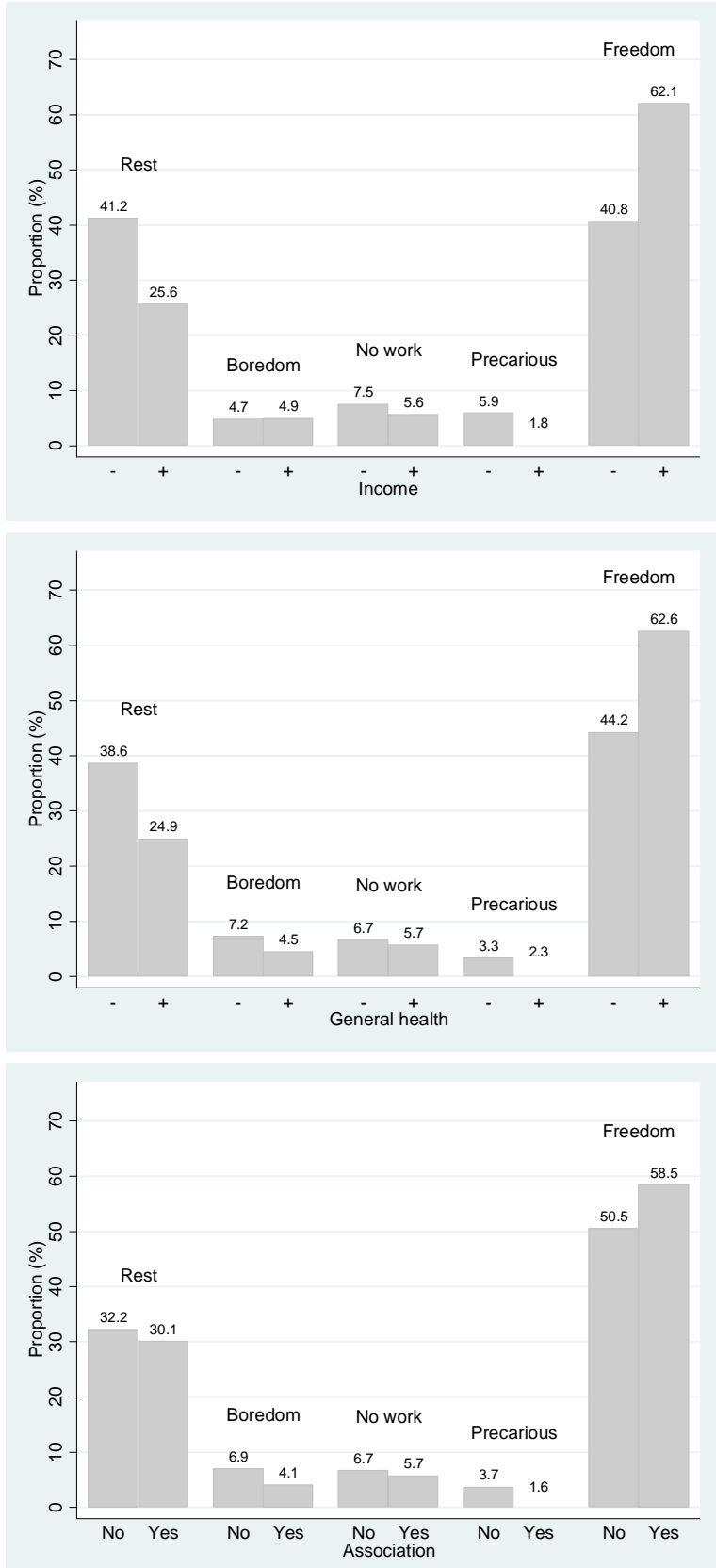

Notes: On the x axis, "-" denotes low income or poor health, "+" denotes high income or good health, "No" means that the individual is not involved in an association, and "Yes" means that she is. 


\section{Supplementary material}

Table A: Descriptive statistics for explanatory and control variables

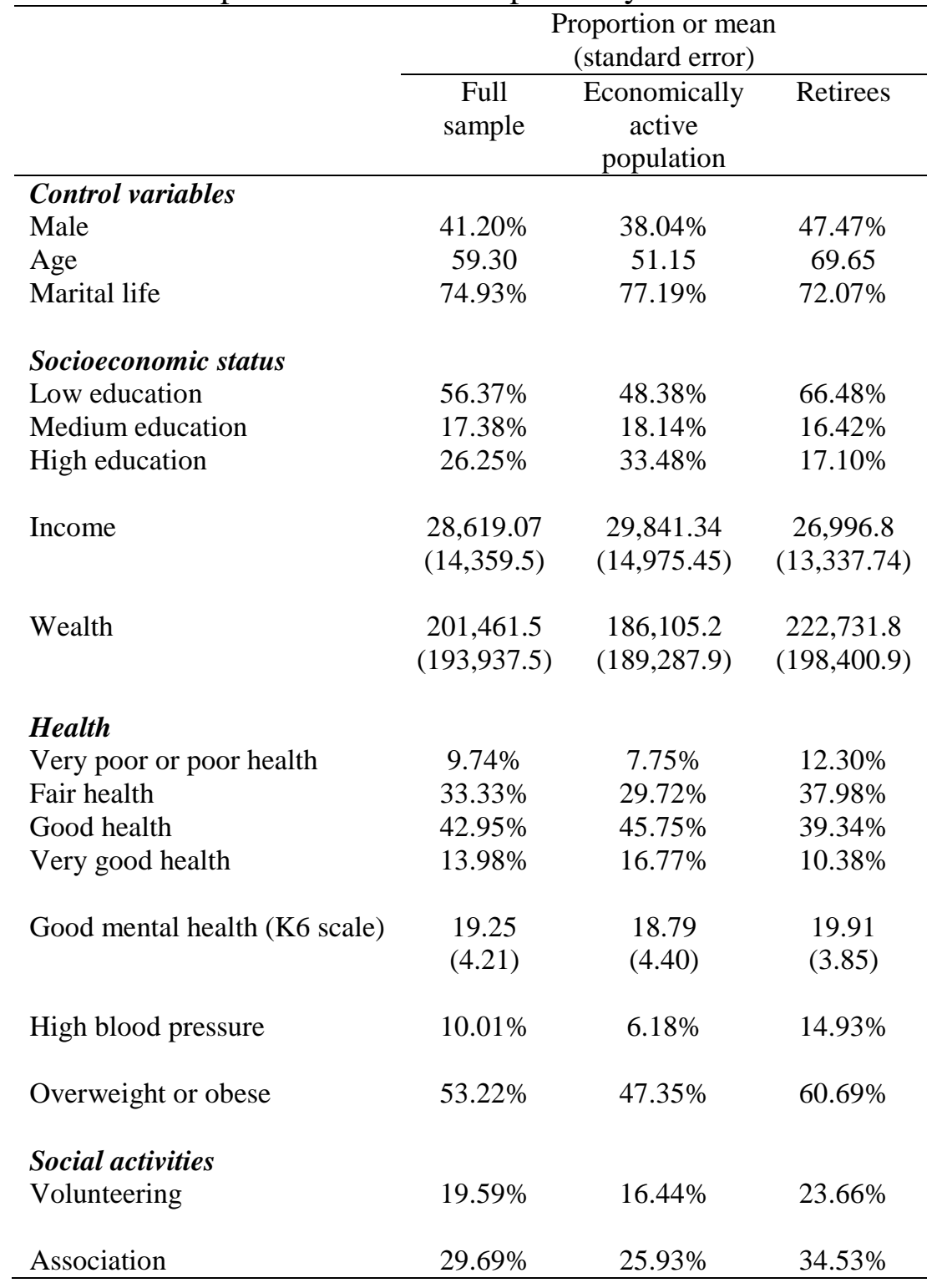




\section{Supplementary material}

Table B: Correlates of perception of retirement (full model)

(economically active population and retirees)

\begin{tabular}{|c|c|c|c|c|c|c|c|c|}
\hline & $(1)$ & $(2)$ & (3) & $(4)$ & $(5)$ & $(6)$ & $(7)$ & $(8)$ \\
\hline & \multicolumn{3}{|c|}{ View of retirement transition } & \multicolumn{5}{|c|}{ Definition of retirement } \\
\hline & Negative & $\begin{array}{l}\text { Neither } \\
\text { negative } \\
\text { nor } \\
\text { positive }\end{array}$ & Positive & Rest & Boredom & $\begin{array}{c}\text { Not } \\
\text { hearing } \\
\text { of } \\
\text { work }\end{array}$ & $\begin{array}{c}\text { Precarious } \\
\text { ness }\end{array}$ & Freedom \\
\hline Men & $\begin{array}{l}-0.013 \\
(0.008)\end{array}$ & $\begin{array}{l}-0.025 \\
(0.016)\end{array}$ & $\begin{array}{c}0.038 \\
(0.025)\end{array}$ & $\begin{array}{c}0.001 \\
(0.024)\end{array}$ & $\begin{array}{c}-0.022 * \\
(0.013)\end{array}$ & $\begin{array}{c}0.014 \\
(0.015)\end{array}$ & $\begin{array}{l}-0.017 \\
(0.011)\end{array}$ & $\begin{array}{c}0.023 \\
(0.025)\end{array}$ \\
\hline Age & $\begin{array}{c}-0.002 * * \\
(0.001)\end{array}$ & $\begin{array}{c}-0.003 * * \\
(0.001)\end{array}$ & $\begin{array}{c}0.005 * * \\
(0.002)\end{array}$ & $\begin{array}{c}-0.004 * * \\
(0.002)\end{array}$ & $\begin{array}{c}0.000 \\
(0.001)\end{array}$ & $\begin{array}{c}-0.003 * * * \\
(0.001)\end{array}$ & $\begin{array}{c}0.003 * * * \\
(0.001)\end{array}$ & $\begin{array}{c}0.004 * * \\
(0.002)\end{array}$ \\
\hline No marital life & $\begin{array}{c}0.022 * * \\
(0.011)\end{array}$ & $\begin{array}{c}0.039 * * \\
(0.018)\end{array}$ & $\begin{array}{c}-0.061 * * \\
(0.029)\end{array}$ & $\begin{array}{c}-0.047 * \\
(0.027)\end{array}$ & $\begin{array}{l}-0.004 \\
(0.015)\end{array}$ & $\begin{array}{l}-0.005 \\
(0.017)\end{array}$ & $\begin{array}{c}0.027 * * \\
(0.013)\end{array}$ & $\begin{array}{c}0.028 \\
(0.030)\end{array}$ \\
\hline $\begin{array}{l}\text { Socioeconomic status } \\
\text { Employed }\end{array}$ & Ref & Ref & Ref & $\operatorname{Ref}$ & Ref & Ref & Ref & Ref \\
\hline Unemployed & $\begin{array}{c}0.048 \\
(0.031)\end{array}$ & $\begin{array}{c}0.064 * * \\
(0.031)\end{array}$ & $\begin{array}{c}-0.111 * \\
(0.062)\end{array}$ & $\begin{array}{l}-0.039 \\
(0.052)\end{array}$ & $\begin{array}{l}0.090^{*} \\
(0.049)\end{array}$ & $\begin{array}{l}-0.020 \\
(0.028)\end{array}$ & $\begin{array}{c}0.051 \\
(0.044)\end{array}$ & $\begin{array}{l}-0.083 \\
(0.067)\end{array}$ \\
\hline Retired & $\begin{array}{l}-0.010 \\
(0.015)\end{array}$ & $\begin{array}{l}-0.019 \\
(0.030)\end{array}$ & $\begin{array}{c}0.028 \\
(0.044)\end{array}$ & $\begin{array}{l}0.078^{*} \\
(0.042)\end{array}$ & $\begin{array}{l}-0.009 \\
(0.021)\end{array}$ & $\begin{array}{c}0.011 \\
(0.027)\end{array}$ & $\begin{array}{c}-0.083 * * * \\
(0.023)\end{array}$ & $\begin{array}{c}0.003 \\
(0.045)\end{array}$ \\
\hline Low edu & Ref & Ref & Ref & Ref & Ref & Ref & Ref & Ref \\
\hline Medium edu & $\begin{array}{c}-0.002 \\
(0.011)\end{array}$ & $\begin{array}{l}-0.003 \\
(0.022)\end{array}$ & $\begin{array}{c}0.005 \\
(0.033)\end{array}$ & $\begin{array}{c}-0.081 * * \\
(0.032)\end{array}$ & $\begin{array}{c}0.017 \\
(0.018)\end{array}$ & $\begin{array}{l}-0.027 \\
(0.019)\end{array}$ & $\begin{array}{c}0.025 \\
(0.017)\end{array}$ & $\begin{array}{l}0.065^{*} \\
(0.034)\end{array}$ \\
\hline High edu & $\begin{array}{l}0.023 * \\
(0.012)\end{array}$ & $\begin{array}{c}0.039 * * \\
(0.019)\end{array}$ & $\begin{array}{c}-0.061 * * \\
(0.031)\end{array}$ & $\begin{array}{c}-0.131 * * * \\
(0.029)\end{array}$ & $\begin{array}{l}0.032 * \\
(0.018)\end{array}$ & $\begin{array}{l}-0.029 \\
(0.018)\end{array}$ & $\begin{array}{c}0.010 \\
(0.015)\end{array}$ & $\begin{array}{c}0.118 * * * \\
(0.033)\end{array}$ \\
\hline $\operatorname{Ln}($ income +1$)$ & $\begin{array}{l}-0.010 \\
(0.006)\end{array}$ & $\begin{array}{l}-0.018 \\
(0.012)\end{array}$ & $\begin{array}{c}0.027 \\
(0.018)\end{array}$ & $\begin{array}{c}-0.070 * * * \\
(0.019)\end{array}$ & $\begin{array}{l}-0.000 \\
(0.012)\end{array}$ & $\begin{array}{l}-0.018 \\
(0.011)\end{array}$ & $\begin{array}{c}-0.025^{* * *} \\
(0.006)\end{array}$ & $\begin{array}{c}0.113 * * * \\
(0.023)\end{array}$ \\
\hline Health & & & & & & & & \\
\hline Very poor or poor & $\begin{array}{c}0.012 \\
(0.018)\end{array}$ & $\begin{array}{c}0.017 \\
(0.026)\end{array}$ & $\begin{array}{l}-0.029 \\
(0.044)\end{array}$ & $\begin{array}{l}-0.004 \\
(0.043)\end{array}$ & $\begin{array}{l}-0.008 \\
(0.025)\end{array}$ & $\begin{array}{c}0.008 \\
(0.028)\end{array}$ & $\begin{array}{l}0.036^{*} \\
(0.021)\end{array}$ & $\begin{array}{l}-0.032 \\
(0.046)\end{array}$ \\
\hline Fair & Ref & Ref & Ref & Ref & Ref & Ref & Ref & Ref \\
\hline Good & $\begin{array}{c}-0.016 \\
(0.010)\end{array}$ & $\begin{array}{l}-0.029 \\
(0.018)\end{array}$ & $\begin{array}{c}0.044 \\
(0.028)\end{array}$ & $\begin{array}{c}-0.063 * * \\
(0.026)\end{array}$ & $\begin{array}{c}-0.023 \\
(0.015)\end{array}$ & $\begin{array}{l}-0.010 \\
(0.017)\end{array}$ & $\begin{array}{c}0.007 \\
(0.012)\end{array}$ & $\begin{array}{c}0.090 * * * \\
(0.029)\end{array}$ \\
\hline Very good & $\begin{array}{c}-0.028 * * \\
(0.012)\end{array}$ & $\begin{array}{c}-0.056^{* *} \\
(0.026)\end{array}$ & $\begin{array}{c}0.084 * * \\
(0.038)\end{array}$ & $\begin{array}{c}-0.067 * \\
(0.037)\end{array}$ & $\begin{array}{c}-0.040 * * \\
(0.018)\end{array}$ & $\begin{array}{l}-0.016 \\
(0.022)\end{array}$ & $\begin{array}{c}0.000 \\
(0.017)\end{array}$ & $\begin{array}{c}0.122 * * * \\
(0.040)\end{array}$ \\
\hline Social activities & & & & & & & & \\
\hline Volunteering & $\begin{array}{c}-0.034 * * * \\
(0.011)\end{array}$ & $\begin{array}{c}-0.062 * * * \\
(0.020)\end{array}$ & $\begin{array}{c}0.096 * * * \\
(0.031)\end{array}$ & $\begin{array}{c}0.045 \\
(0.029)\end{array}$ & $\begin{array}{l}-0.006 \\
(0.017)\end{array}$ & $\begin{array}{l}-0.024 \\
(0.020)\end{array}$ & $\begin{array}{c}-0.061 * * \\
(0.024)\end{array}$ & $\begin{array}{c}0.045 \\
(0.033)\end{array}$ \\
\hline Association & $\begin{array}{c}-0.016 \\
(0.010)\end{array}$ & $\begin{array}{c}-0.029 * \\
(0.018)\end{array}$ & $\begin{array}{l}0.045^{*} \\
(0.027)\end{array}$ & $\begin{array}{l}-0.012 \\
(0.026)\end{array}$ & $\begin{array}{l}-0.007 \\
(0.014)\end{array}$ & $\begin{array}{c}0.012 \\
(0.016)\end{array}$ & $\begin{array}{c}-0.046^{* *} \\
(0.018)\end{array}$ & $\begin{array}{l}0.054^{*} \\
(0.028)\end{array}$ \\
\hline Observations & 1,568 & 1,568 & 1,568 & 1,563 & 1,563 & 1,563 & 1,563 & 1,563 \\
\hline
\end{tabular}

Notes: Each column corresponds to a specific regression. Columns (1) to (3) contain marginal effect from an ordered logit model. Columns (4) to (8) report marginal effects from a multinomial logit model. "Controls 2" and labour market status are included. Standard errors in parentheses.

$* * * \mathrm{p}<0.01, * * \mathrm{p}<0.05, * \mathrm{p}<0.1$ 


\section{Supplementary material}

Table C: Interaction effects between social condition and age, for economically active respondents and retirees

\begin{tabular}{|c|c|c|c|c|c|c|c|}
\hline & $(1)$ & $(2)$ & $(3)$ & $(4)$ & $(5)$ & $(6)$ & $(7)$ \\
\hline & \multicolumn{2}{|c|}{$\begin{array}{l}\text { View of the } \\
\text { retirement transition }\end{array}$} & \multicolumn{5}{|c|}{ Definition of retirement } \\
\hline & Negative & Positive & Rest & Boredom & $\begin{array}{c}\text { Not } \\
\text { hearing } \\
\text { of } \\
\text { work }\end{array}$ & $\begin{array}{c}\text { Precarious } \\
\text { ness }\end{array}$ & Freedom \\
\hline \multicolumn{8}{|c|}{ Panel A. Interaction with education } \\
\hline Age & $\begin{array}{c}-0.004 * * * \\
(0.001)\end{array}$ & $\begin{array}{l}0.004 * \\
(0.002)\end{array}$ & $\begin{array}{l}-0.002 \\
(0.002)\end{array}$ & $\begin{array}{l}-0.000 \\
(0.001)\end{array}$ & $\begin{array}{c}-0.004 * * * \\
(0.001)\end{array}$ & $\begin{array}{c}0.003 * * * \\
(0.001)\end{array}$ & $\begin{array}{c}0.003 \\
(0.002)\end{array}$ \\
\hline Low or medium edu & Ref & Ref & Ref & Ref & Ref & Ref & Ref \\
\hline High edu & $\begin{array}{l}-0.110 \\
(0.089)\end{array}$ & $\begin{array}{l}-0.118 \\
(0.153)\end{array}$ & $\begin{array}{l}0.241 * \\
(0.140)\end{array}$ & $\begin{array}{l}-0.037 \\
(0.077)\end{array}$ & $\begin{array}{l}-0.118 \\
(0.087)\end{array}$ & $\begin{array}{c}0.022 \\
(0.066)\end{array}$ & $\begin{array}{l}-0.108 \\
(0.151)\end{array}$ \\
\hline High edu $*$ Age & $\begin{array}{c}0.002 \\
(0.002)\end{array}$ & $\begin{array}{c}0.001 \\
(0.003)\end{array}$ & $\begin{array}{c}-0.006 * * * \\
(0.002)\end{array}$ & $\begin{array}{c}0.001 \\
(0.001)\end{array}$ & $\begin{array}{c}0.002 \\
(0.002)\end{array}$ & $\begin{array}{l}-0.000 \\
(0.001)\end{array}$ & $\begin{array}{c}0.004 \\
(0.003)\end{array}$ \\
\hline \multicolumn{8}{|c|}{ Panel B. Interaction with income } \\
\hline Age & $\begin{array}{l}-0.014 \\
(0.011)\end{array}$ & $\begin{array}{l}0.005 \\
(0.019)\end{array}$ & $\begin{array}{c}0.061 * * * \\
(0.017)\end{array}$ & $\begin{array}{l}-0.007 \\
(0.009)\end{array}$ & $\begin{array}{c}0.006 \\
(0.011)\end{array}$ & $\begin{array}{c}0.004 \\
(0.008)\end{array}$ & $\begin{array}{c}-0.064 * * * \\
(0.018)\end{array}$ \\
\hline $\operatorname{Ln}($ income +1$)$ & $\begin{array}{l}-0.078 \\
(0.060)\end{array}$ & $\begin{array}{c}0.034 \\
(0.103)\end{array}$ & $\begin{array}{c}0.319 * * * \\
(0.094)\end{array}$ & $\begin{array}{l}-0.031 \\
(0.052)\end{array}$ & $\begin{array}{c}0.040 \\
(0.059)\end{array}$ & $\begin{array}{l}-0.036 \\
(0.044)\end{array}$ & $\begin{array}{c}-0.291 * * * \\
(0.101)\end{array}$ \\
\hline Ln(income +1$) *$ Age & $\begin{array}{c}0.001 \\
(0.001)\end{array}$ & $\begin{array}{l}-0.000 \\
(0.002)\end{array}$ & $\begin{array}{c}-0.006 * * * \\
(0.002)\end{array}$ & $\begin{array}{c}0.001 \\
(0.001)\end{array}$ & $\begin{array}{l}-0.001 \\
(0.001)\end{array}$ & $\begin{array}{l}-0.000 \\
(0.001)\end{array}$ & $\begin{array}{c}0.007 * * * \\
(0.002)\end{array}$ \\
\hline \multicolumn{8}{|c|}{ Panel C. Interaction with health } \\
\hline 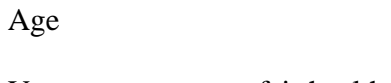 & $\begin{array}{l}-0.002^{*} \\
(0.001)\end{array}$ & $\begin{array}{c}0.004 \\
(0.002)\end{array}$ & $\begin{array}{l}-0.002 \\
(0.002)\end{array}$ & $\begin{array}{c}0.000 \\
(0.001)\end{array}$ & $\begin{array}{c}-0.004 * * * \\
(0.001)\end{array}$ & $\begin{array}{c}0.003 * * * \\
(0.001)\end{array}$ & $\begin{array}{c}0.002 \\
(0.002)\end{array}$ \\
\hline Very poor, poor, or fair health & Ref & Ref & Ref & Ref & Ref & Ref & Ref \\
\hline Good/very good health & $\begin{array}{c}0.026 \\
(0.082)\end{array}$ & $\begin{array}{c}0.005 \\
(0.140)\end{array}$ & $\begin{array}{c}0.206 \\
(0.128)\end{array}$ & $\begin{array}{l}-0.039 \\
(0.071)\end{array}$ & $\begin{array}{l}-0.057 \\
(0.079)\end{array}$ & $\begin{array}{c}0.031 \\
(0.060)\end{array}$ & $\begin{array}{l}-0.142 \\
(0.138)\end{array}$ \\
\hline Good/very good health * Age & $\begin{array}{l}-0.001 \\
(0.001)\end{array}$ & $\begin{array}{c}0.001 \\
(0.002)\end{array}$ & $\begin{array}{c}-0.005^{* *} \\
(0.002)\end{array}$ & $\begin{array}{c}0.000 \\
(0.001)\end{array}$ & $\begin{array}{c}0.001 \\
(0.001)\end{array}$ & $\begin{array}{l}-0.001 \\
(0.001)\end{array}$ & $\begin{array}{l}0.004 * \\
(0.002)\end{array}$ \\
\hline \multicolumn{8}{|c|}{ Panel D. Interaction with volunteering } \\
\hline Age & $\begin{array}{c}-0.004 * * * \\
(0.001)\end{array}$ & $\begin{array}{l}0.004 * \\
(0.002)\end{array}$ & $\begin{array}{c}-0.003 * \\
(0.002)\end{array}$ & $\begin{array}{c}0.000 \\
(0.001)\end{array}$ & $\begin{array}{c}-0.003 * * \\
(0.001)\end{array}$ & $\begin{array}{c}0.003 * * * \\
(0.001)\end{array}$ & $\begin{array}{l}0.004 * \\
(0.002)\end{array}$ \\
\hline Volunteering & $\begin{array}{c}-0.207 * * \\
(0.103)\end{array}$ & $\begin{array}{l}-0.007 \\
(0.176)\end{array}$ & $\begin{array}{c}0.257 \\
(0.161)\end{array}$ & $\begin{array}{l}-0.009 \\
(0.089)\end{array}$ & $\begin{array}{c}0.015 \\
(0.100)\end{array}$ & $\begin{array}{l}-0.078 \\
(0.076)\end{array}$ & $\begin{array}{l}-0.184 \\
(0.174)\end{array}$ \\
\hline Volunteering * Age & $\begin{array}{l}0.003 * \\
(0.002)\end{array}$ & $\begin{array}{c}0.002 \\
(0.003)\end{array}$ & $\begin{array}{l}-0.004 \\
(0.003)\end{array}$ & $\begin{array}{c}0.000 \\
(0.001)\end{array}$ & $\begin{array}{l}-0.001 \\
(0.002)\end{array}$ & $\begin{array}{c}0.001 \\
(0.001)\end{array}$ & $\begin{array}{c}0.004 \\
(0.003)\end{array}$ \\
\hline \multicolumn{8}{|c|}{ Panel E. Interaction with association } \\
\hline Age & $\begin{array}{c}-0.003 * * \\
(0.001)\end{array}$ & $\begin{array}{c}0.004 \\
(0.002)\end{array}$ & $\begin{array}{c}-0.005 * * \\
(0.002)\end{array}$ & $\begin{array}{c}0.001 \\
(0.001)\end{array}$ & $\begin{array}{c}-0.003 * * \\
(0.001)\end{array}$ & $\begin{array}{c}0.003 * * * \\
(0.001)\end{array}$ & $\begin{array}{c}0.005 * * \\
(0.002)\end{array}$ \\
\hline Association & $\begin{array}{c}0.006 \\
(0.087)\end{array}$ & $\begin{array}{l}-0.030 \\
(0.150)\end{array}$ & $\begin{array}{l}-0.220 \\
(0.137)\end{array}$ & $\begin{array}{c}0.084 \\
(0.076)\end{array}$ & $\begin{array}{c}0.071 \\
(0.085)\end{array}$ & $\begin{array}{l}-0.055 \\
(0.064)\end{array}$ & $\begin{array}{c}0.120 \\
(0.148)\end{array}$ \\
\hline Association $*$ Age & $\begin{array}{l}-0.000 \\
(0.001)\end{array}$ & $\begin{array}{c}0.001 \\
(0.002)\end{array}$ & $\begin{array}{c}0.003 \\
(0.002)\end{array}$ & $\begin{array}{c}-0.002 \\
(0.001)\end{array}$ & $\begin{array}{l}-0.001 \\
(0.001)\end{array}$ & $\begin{array}{c}0.000 \\
(0.001)\end{array}$ & $\begin{array}{l}-0.001 \\
(0.002)\end{array}$ \\
\hline Observations & 1,568 & 1,568 & 1,563 & 1,563 & 1,563 & 1,563 & 1,563 \\
\hline
\end{tabular}

Notes: Each column and panel corresponds to a specific regression. We use linear probability models. "Controls 2" (i.e. gender, age, marital status, education, income, self-assessed health, volunteering, and association) and labour market status are included. Standard errors in parentheses.

$* * * \mathrm{p}<0.01, * * \mathrm{p}<0.05, * \mathrm{p}<0.1$. 


\section{Supplementary material}

Table D: Perception of retirement and wellbeing for retirees

\begin{tabular}{|c|c|c|c|c|c|}
\hline & (1) & (2) & (3) & (4) & $(5)$ \\
\hline & $\begin{array}{c}\text { Satisfaction } \\
\text { with } \\
\text { finances }\end{array}$ & $\begin{array}{c}\text { Satisfaction } \\
\text { with } \\
\text { leisure }\end{array}$ & $\begin{array}{l}\text { Satisfaction } \\
\text { with } \\
\text { social life }\end{array}$ & $\begin{array}{c}\text { Satisfaction } \\
\text { with } \\
\text { health }\end{array}$ & $\begin{array}{c}\text { Satisfaction } \\
\text { with } \\
\text { housing }\end{array}$ \\
\hline \multicolumn{6}{|c|}{ Panel A. View of retirement. Controls 1 included } \\
\hline Negative & $\begin{array}{c}0.59 \\
(0.39)\end{array}$ & $\begin{array}{l}-0.13 \\
(0.46)\end{array}$ & $\begin{array}{l}-0.44 \\
(0.30)\end{array}$ & $\begin{array}{l}-0.63 * \\
(0.34)\end{array}$ & $\begin{array}{l}-0.06 \\
(0.32)\end{array}$ \\
\hline Neither negative nor positive & Ref & Ref & Ref & Ref & Ref \\
\hline Positive & $\begin{array}{c}0.54 * * * \\
(0.18)\end{array}$ & $\begin{array}{c}0.95 * * * \\
(0.21)\end{array}$ & $\begin{array}{c}0.48 * * * \\
(0.14)\end{array}$ & $\begin{array}{c}0.40 * * \\
(0.16)\end{array}$ & $\begin{array}{c}0.50 * * * \\
(0.15)\end{array}$ \\
\hline Controls 1 & Yes & Yes & Yes & Yes & Yes \\
\hline Observations & 686 & 671 & 708 & 693 & 702 \\
\hline \multicolumn{6}{|c|}{ Panel B. View of retirement. Controls 2 included } \\
\hline Negative & $\begin{array}{c}0.85 * * \\
(0.36)\end{array}$ & $\begin{array}{c}0.08 \\
(0.42)\end{array}$ & $\begin{array}{l}-0.14 \\
(0.31)\end{array}$ & $\begin{array}{c}0.02 \\
(0.27)\end{array}$ & $\begin{array}{c}0.37 \\
(0.33)\end{array}$ \\
\hline Neither negative nor positive & Ref & Ref & Ref & Ref & Ref \\
\hline Positive & $\begin{array}{c}0.43 * * * \\
(0.16)\end{array}$ & $\begin{array}{c}0.79 * * * \\
(0.19)\end{array}$ & $\begin{array}{c}0.45^{* * * *} \\
(0.14)\end{array}$ & $\begin{array}{l}0.21 * \\
(0.12)\end{array}$ & $\begin{array}{c}0.38 * * \\
(0.15)\end{array}$ \\
\hline Controls 2 & Yes & Yes & Yes & Yes & Yes \\
\hline Observations & 644 & 632 & 661 & 650 & 655 \\
\hline \multicolumn{6}{|c|}{ Panel C. Definition of retirement. Controls 1 included } \\
\hline Rest & Ref & Ref & Ref & Ref & Ref \\
\hline Boredom & $\begin{array}{c}0.75 * * \\
(0.36)\end{array}$ & $\begin{array}{c}0.31 \\
(0.43)\end{array}$ & $\begin{array}{l}-0.44 \\
(0.29)\end{array}$ & $\begin{array}{l}-0.34 \\
(0.33)\end{array}$ & $\begin{array}{c}0.19 \\
(0.30)\end{array}$ \\
\hline Not hearing of work & $\begin{array}{l}-0.36 \\
(0.36)\end{array}$ & $\begin{array}{l}-0.39 \\
(0.42)\end{array}$ & $\begin{array}{l}-0.29 \\
(0.29)\end{array}$ & $\begin{array}{c}-0.93 * * * \\
(0.32)\end{array}$ & $\begin{array}{l}-0.09 \\
(0.30)\end{array}$ \\
\hline Precariousness & $\begin{array}{c}-1.40 * * * \\
(0.50)\end{array}$ & $\begin{array}{c}-2.16 * * * \\
(0.57)\end{array}$ & $\begin{array}{c}0.43 \\
(0.39)\end{array}$ & $\begin{array}{c}-1.31 * * * \\
(0.46)\end{array}$ & $\begin{array}{c}-1.03 * * \\
(0.41)\end{array}$ \\
\hline Freedom & $\begin{array}{c}0.95 * * * \\
(0.19)\end{array}$ & $\begin{array}{c}1.19 * * * \\
(0.22)\end{array}$ & $\begin{array}{c}0.42 * * * \\
(0.15)\end{array}$ & $\begin{array}{c}0.45^{* * * *} \\
(0.16)\end{array}$ & $\begin{array}{c}0.61 * * * \\
(0.15)\end{array}$ \\
\hline Controls 1 & Yes & Yes & Yes & Yes & Yes \\
\hline Observations & 686 & 671 & 708 & 693 & 701 \\
\hline \multicolumn{6}{|c|}{ Panel D. Definition of retirement. Controls 2 included } \\
\hline Rest & Ref & Ref & Ref & Ref & Ref \\
\hline Boredom & $\begin{array}{c}0.23 \\
(0.34)\end{array}$ & $\begin{array}{l}-0.27 \\
(0.40)\end{array}$ & $\begin{array}{l}-0.28 \\
(0.30)\end{array}$ & $\begin{array}{l}-0.34 \\
(0.25)\end{array}$ & $\begin{array}{c}0.11 \\
(0.31)\end{array}$ \\
\hline Not hearing of work & $\begin{array}{l}-0.42 \\
(0.34)\end{array}$ & $\begin{array}{l}-0.43 \\
(0.38)\end{array}$ & $\begin{array}{l}-0.02 \\
(0.29)\end{array}$ & $\begin{array}{c}-0.75 * * * \\
(0.25)\end{array}$ & $\begin{array}{l}-0.14 \\
(0.30)\end{array}$ \\
\hline Precariousness & $\begin{array}{l}-0.85^{*} \\
(0.48)\end{array}$ & $\begin{array}{c}-1.69 * * * \\
(0.55)\end{array}$ & $\begin{array}{c}0.46 \\
(0.42)\end{array}$ & $\begin{array}{c}-0.93 * * * \\
(0.35)\end{array}$ & $\begin{array}{l}-0.28 \\
(0.43)\end{array}$ \\
\hline Freedom & $\begin{array}{c}0.18 \\
(0.18)\end{array}$ & $\begin{array}{c}0.33 \\
(0.21)\end{array}$ & $\begin{array}{l}0.39 * * \\
(0.16)\end{array}$ & $\begin{array}{l}-0.03 \\
(0.13)\end{array}$ & $\begin{array}{l}0.32 * \\
(0.16)\end{array}$ \\
\hline Controls 2 & Yes & Yes & Yes & Yes & Yes \\
\hline Observations & 643 & 631 & 660 & 649 & 653 \\
\hline
\end{tabular}

Notes: Each column and panel corresponds to a different regression. We estimate OLS models. "Controls 1" (i.e. gender, age, and marital status) are included in Panels A and C. "Controls 2" (i.e. gender, age, marital status, education, income, general health, volunteering, and association) are included in Panels B and D. Standard errors in parentheses. $* * * \mathrm{p}<0.01, * * \mathrm{p}<0.05, * \mathrm{p}<0.1$ 


\section{Notes}

${ }^{\mathrm{i}}$ See https://www.insee.fr/fr/statistiques/1906664?sommaire=1906743\#titre-bloc-3.

ii See: Libault D. (2019). Rapport de la concertation Grand âge et autonomie. Link: https://solidaritessante.gouv.fr/affaires-sociales/personnes-agees/concertation-grand-age-et-autonomie/article/rapport-de-la-concertationgrand-age-et-autonomie.

iii In this context, a large literature in Economics studies the effect of retirement on health and wellbeing.

iv measured with the Attitudes Toward Own Ageing subscale from Lawton's (1975) Philadelphia Geriatric Centre Morale Scale.

${ }^{v}$ See https://www.statistiques-recherches.cnav.fr/age-de-depart-a-la-retraite.html.

${ }^{v i}$ The sample includes employed individuals from the general retirement scheme ("salariés du régime genéral").

vii Our article also relates to the international economics literature on the causal impact of retirement on mental health and wellbeing. This series of articles employ specific methodologies, such as the instrumental variable technique, to quantify the causal effect. Findings are somewhat contradictory: while several articles document a negative effect of retirement (Dave, Rashad, and Spasojevic 2008), other articles find a positive impact (Apouey, Guven, and Senik 2019; Zhu 2016). Nishimura, Oikawa, and Motegi (2018) argue that differences in results are often due to differences in the choice of the analysis method.

viii In French, the question is the following: "Avez-vous une vision positive ou négative du passage à la retraite ? (1) Positive ; (2) Négative ; (3) Ni positive ni négative."

${ }^{\text {ix }}$ In French: "Parmi les propositions suivantes, quelle est celle qui définit le mieux, pour vous, la retraite ? (1) Un repos bien mérité ; (2) Une période où l'on peut parfois s'ennuyer, se sentir inutile, ou avoir un sentiment de vide ; (3) Le plaisir de ne plus entendre parler du travail ; (4) Le risque de tomber dans la précarité ; (5) Un sentiment de liberté, de renaissance, d'être au début d'une deuxième vie."

${ }^{\mathrm{x}}$ This dummy is constructed using self-reported height and weight.

${ }^{x i}$ More precisely, the effect of our income variable $(\log ($ income +1$))$ on "rest" decreases from $-0.005(=0.319$ $0.006 * 54$ ) at age 54 to -0.185 at age 84 . The effect of the income measure on "freedom" increases from 0.003 at age 42 to 0.297 at age 84 . 